\title{
Experimental Study on Various Solar Still Designs
}

\author{
T. Arunkumar, ${ }^{1}$ K. Vinothkumar, ${ }^{2}$ Amimul Ahsan, ${ }^{3}$ R. Jayaprakash, ${ }^{1}$ and Sanjay Kumar ${ }^{4}$ \\ ${ }^{1}$ Solar Energy Laboratory, Department of Physics, Sri Ramakrishna Mission Vidyalaya, College of Arts and Science, \\ Coimbatore 641020, India \\ ${ }^{2}$ Research and Development (Renewable Energy), NSP Green Energy Technologies, Pvt. Ltd. Chennai 603 209, India \\ ${ }^{3}$ Department of Civil Engineering, Faculty of Engineering, Green Engineering and Sustainable Technology Lab, \\ Institute of Advanced Technology, University Putra, 43400 Serdang, Malaysia \\ ${ }^{4}$ Centre for Renewable Energy and Environmental Research, P.O. Box-5, Muzaffarpur 842001, India
}

Correspondence should be addressed to R. Jayaprakash, jprakash_jpr@rediffmail.com

Received 4 April 2012; Accepted 3 May 2012

Academic Editors: S. P. Ahrenkiel and S. Senthilarasu

Copyright $\odot 2012$ T. Arunkumar et al. This is an open access article distributed under the Creative Commons Attribution License, which permits unrestricted use, distribution, and reproduction in any medium, provided the original work is properly cited.

\begin{abstract}
Humankind has depended for ages on underground water reservoirs for its fresh water needs. But these sources do not always prove to be useful due to the presence of excessive salinity in the water. In this paper, the fabrication of seven solar still designs such as spherical solar still, pyramid solar still, hemispherical solar still, double basin glass solar still, concentrator coupled single slope solar still, tubular solar still and tubular solar still coupled with pyramid solar still and their performance evaluation in converting brackish water into fresh water for drinking are presented. The experiment was constructed and tested during January to May 2011. All the solar stills were operated in the same climatic conditions to analyze the influence of the modifications on the productivity. From the observations, the compound parabolic concentrator-assisted tubular solar still shows the maximum yield.
\end{abstract}

\section{Introduction}

Solar energy can be used either for seawater desalination by producing the thermal energy required to drive the phase change processes or by generating the electricity required to drive the membrane processes. Solar desalination systems are classified into direct and indirect collection systems. As their name imply, direct-collection systems use solar-energy to produce distillate directly in the solar collector, whereas in indirect collection systems, two sub-systems are employed. Conventional desalination systems are similar to solar systems because the same type of equipment is applied. The prime difference is that in the former, either a conventional boiler is used to provide the required heat or mains electricity is used to provide the required electric power, whereas in the latter, solar energy is applied [1]. Many papers have addressed solar stills of various configurations, including [26]. More specific studies include a hemispherical solar still $[7,8]$, pyramid solar still $[9,10]$, double-basin solar still [11-15], triple basin solar still [16], multiple basin solar still $[17,18]$, inverted absorber solar still [19-22], tubular solar stills [23-26], compound parabolic concentrator (CPC) solar still [27], weir-type cascade solar still [28, 29], wick-type [30], inverted absorber solar still [31], portable active solar still [32], integrated basin solar still with a sandy reservoir [33], titled wick-type with flat plate bottom reflector [34], fin [35], active vibratory solar still [36], and a plastic solar still [37].

In this paper, the fabrication and performance evaluation of seven solar still designs are presented. The ASTER GDEM 30 meter digital elevation data was used to derive the study area map in the ArcGIS platform (ArcGIS, version 9). Figure 1 shows the hill shade and contour pattern of the study area. The contour lines show that the maximum elevation is in the North-West zone of the study site, while the minimum elevation is in the East zone.

\section{Mechanism}

The principle of pure water production from saline water using different designs of a solar water distillation technique is the same. The saline water in the trough mostly absorbs the solar radiation transmitting through the cover. The cover and 


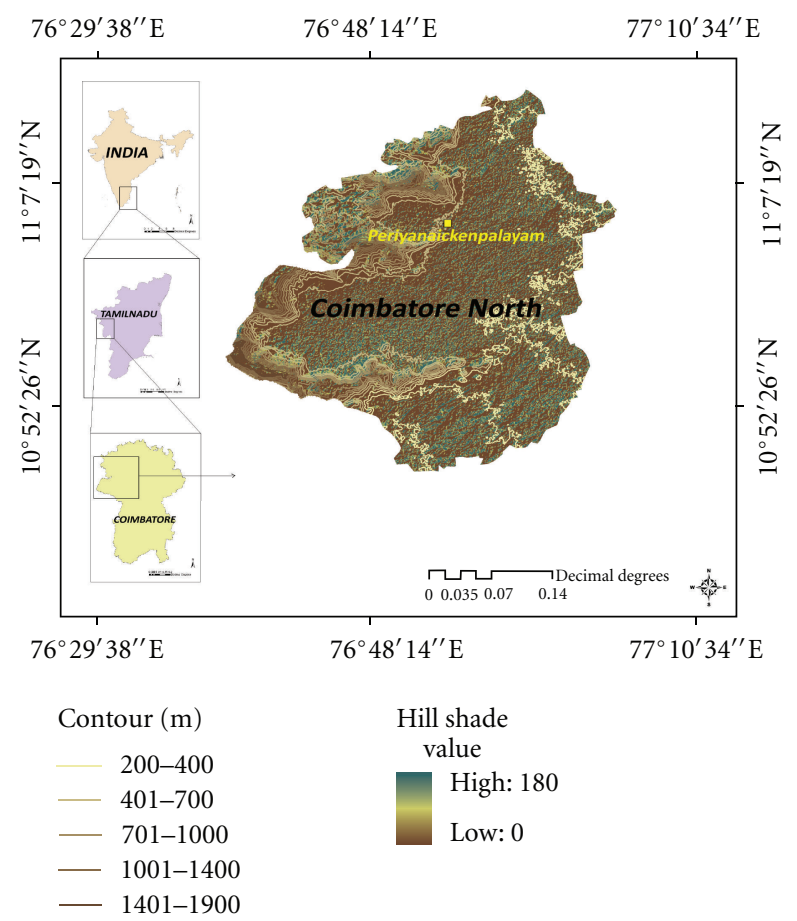

FIGURE 1: The map shows hill shade and contour pattern of the study area.

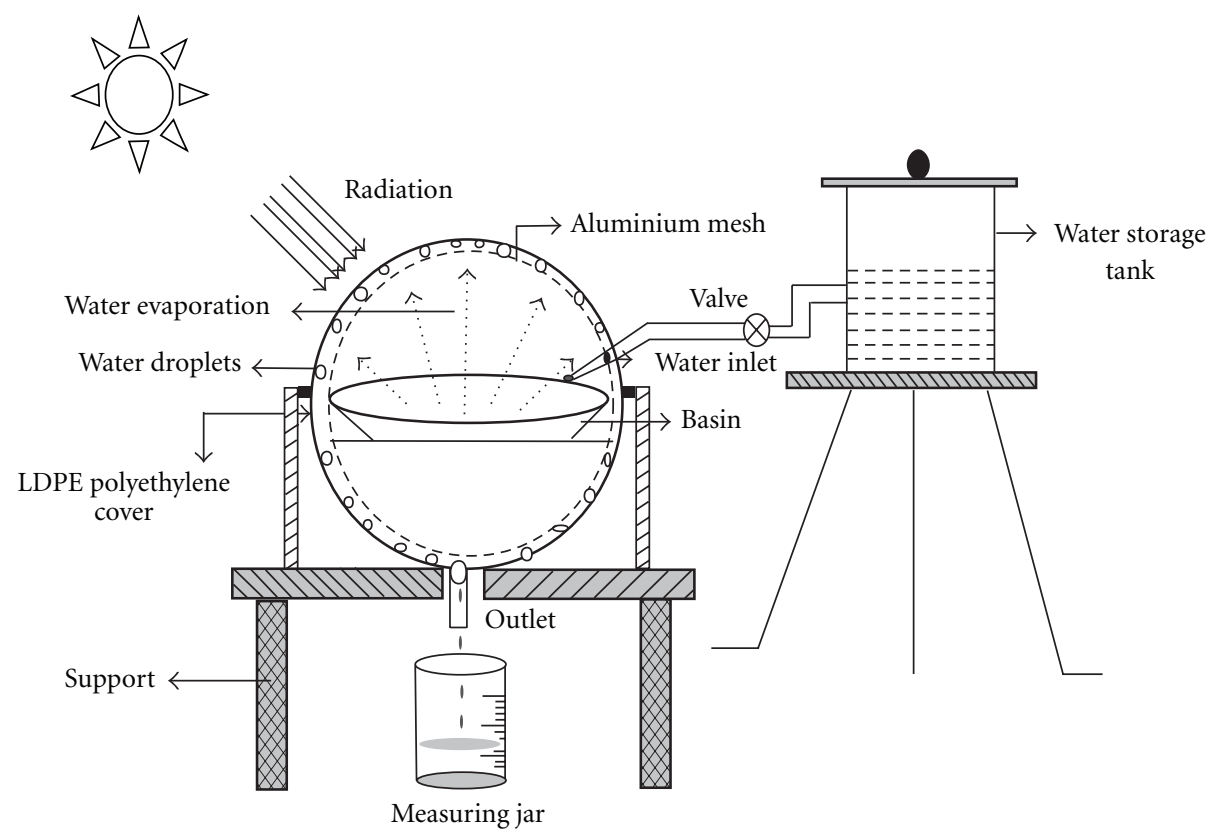

Figure 2: Schematic view of spherical solar still.

the trough absorb the rest. Thus, the saline water is heated up to evaporates. The water vapor density of the humid air increases due to evaporation from the water surface. The water vapor condensed at the inner surface of the cover, releases its latent heat due to evaporation. Finally, the condensed water trickles down due to gravity and is stored in a collector [38].

\section{Fabrication Details}

3.1. Spherical Solar Still. A spherical solar still design with collector area of $0.28 \mathrm{~m}^{2}$ is presented. The still consists of a shallow circular basin of diameter $0.60 \mathrm{~m}$ that is made of steel. The circular absorber basin is coated with black paint for maximum absorption of incident solar radiation. The circular basin is fixed at the middle of the spherical 


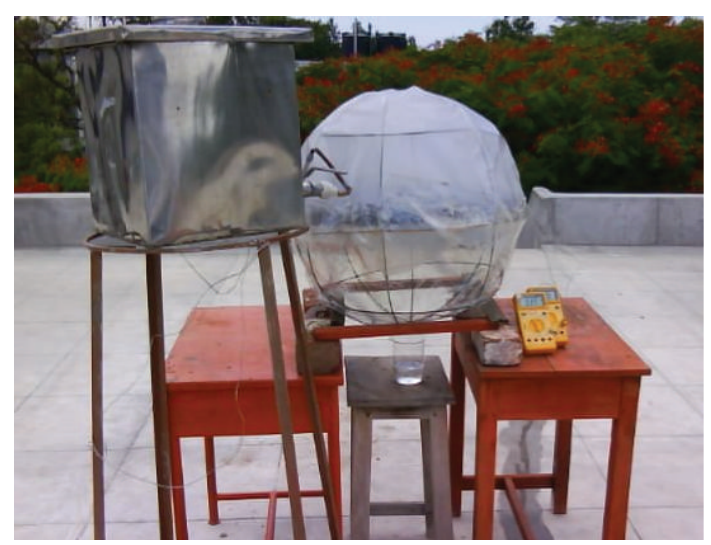

FIGURE 3: Pictorial view of Spherical Solar Still.

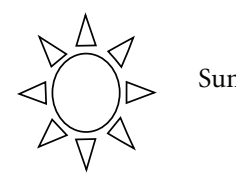

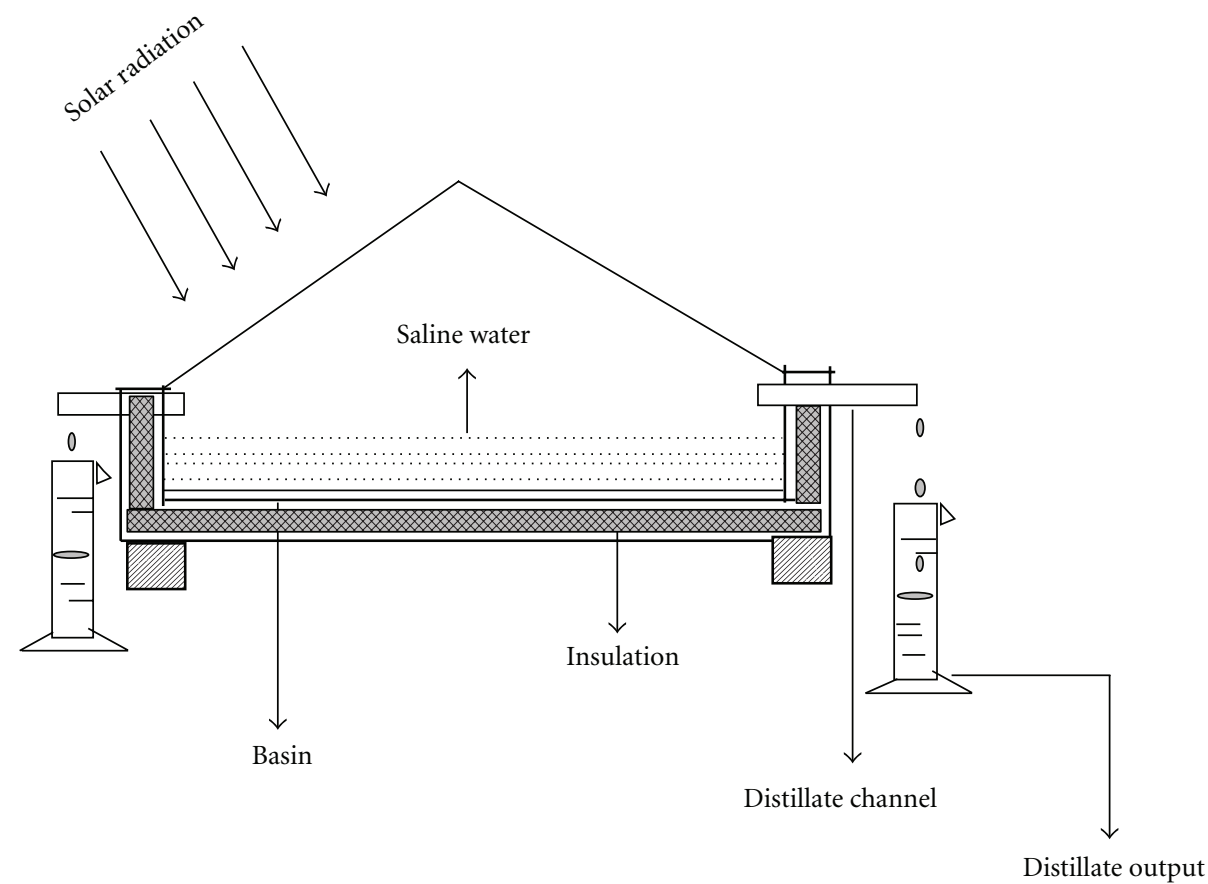

FIGURE 4: Schematic view of pyramid solar still.

aluminum mesh at radial height of $0.28 \mathrm{~m}$. The saline water is stored in a basin with a capacity of 16 liters. The basin in the spherical solar still is fitted without having any physical contact with the top cover made of low-density polyethylene (LDPE) sheet. The LDPE sheet of thickness $0.107 \mathrm{~mm}$ is spread over the spherical mesh. A gap of $0.03 \mathrm{~m}$ is maintained between the circular basin and top cover. The evaporated water, which is condensed on the top cover, passes between this gap, and drips down towards the distilled water collection segment as illustrated in Figures 2 and 3, shows the pictorial diagram of the spherical solar still with total height of about $0.63 \mathrm{~m}$.

3.2. Pyramid Solar Still. A pyramidal glass solar still design with collector area of $1.21 \mathrm{~m}^{2}(1.10 \mathrm{~m} \times 1.10 \mathrm{~m})$ is presented as illustrated in Figures 4 and 5. The still is filled with saline water to height of $0.05 \mathrm{~m}$. From the economic point of view, the solar still with sawdust insulating material has less cost of fabrication. Consequently, the cost of fresh water production is less. In the view of ecofriendly material, saw dust would 


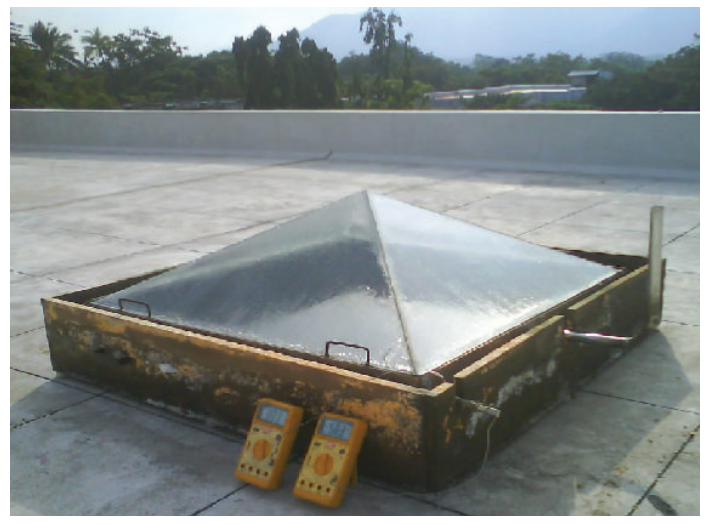

FIGURe 5: Pictorial view of pyramid solar still.

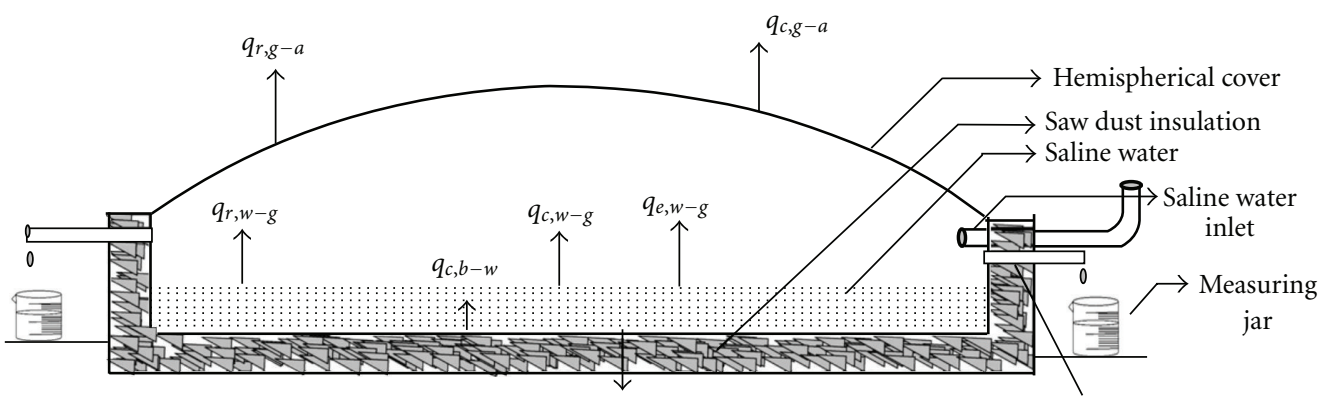

Figure 6: Schematic view of hemispherical solar still [8].

be a good alternative for glass wool. The water storage basin of the still is constructed with dimension $0.95 \mathrm{~m} \times 0.95 \mathrm{~m} \times$ $0.10 \mathrm{~m}$ of mild steel. The water storage segment is provided of diameter $0.90 \mathrm{~m}$, and the remaining $0.05 \mathrm{~m}$ is allowed for the water collection segment.

3.3. Hemispherical Solar Still. The water storage basin of the hemispherical still is constructed with a diameter of $0.95 \mathrm{~m}$ and a height of $0.10 \mathrm{~m}$ using mild steel as illustrated in Figures 6 and 7. The water storage basin is painted black to increase the absorptivity. The still was filled with saline water to a height of $0.05 \mathrm{~m}$. The top hemispherical cover of diameter $0.945 \mathrm{~m}$ and height $0.20 \mathrm{~m}$ is constructed of transparent acrylic sheet of $3 \mathrm{~mm}$ thickness with solar transmittance equal to $88 \%$. The outer box of the still is constructed of wood of thickness $4 \mathrm{~mm}$ with the dimension $1.10 \mathrm{~m} \times 1.10 \mathrm{~m} \times 0.25 \mathrm{~m}$. The bottom of the basin is filled with sawdust (to support the weight of the basin) up to a height of $0.15 \mathrm{~m}$. The sides of the basin are insulated with the glass wool.

3.4. Double-Basin Solar Still. A double-basin experimental solar still is fabricated as shown in Figures 8, 9, and 10. The overall size of the inner basin is $590 \mathrm{~mm} \times 440 \mathrm{~mm} \times 440 \mathrm{~mm}$ and the outer basin is $600 \mathrm{~mm} \times 460 \mathrm{~mm} \times 460 \mathrm{~mm}$. The solar still has a $3 \mathrm{~mm}$ thick top cover, inclined at $17^{\circ}$ on all the sides, and supported by steel frames. The upper basin is partitioned into three segments to avoid the formation of dry spots on the higher portion of the inner glass cover. Silicone rubber sealant has been used to seal off and prevent the water leakage between the boxes of the still. A hole in the basin's sidewall allows saline or wastewater filling, as well as collecting the condensed water. Moreover, this is also used for inserting the thermocouple wires required for temperature measurements. When the still is in operation, the hole is closed with an insulating material to avoid heat and vapor losses.

3.5. Tubular Solar Still. A CPC concentric tubular solar still design with a rectangular absorber is presented as shown in Figures 11, 12, 13, and 14 and the specification shown in Table 1. The inner and outer circular tubes are positioned with a $5 \mathrm{~mm}$ gap for the flowing water and air to cool the outer surface of the inner tube. A rectangular trough of dimension $2 \mathrm{~m} \times 0.03 \mathrm{~m} \times 0.025 \mathrm{~m}$ is designed and coated with black paint using a spray technique. The water level in the trough decreased due to fast evaporation from the basin, so a dry spot appeared in the basin. This is avoided in successive trials by flowing the water continuously in the still with the help of a graduated tube. This tube maintains a constant level of water in the basin independent of the evaporation rate. This continuous supply of water is maintained by a water storage tank, which is kept near the CPC still. The outlet of the storage tank is connected to the inlet of the CPC still. 


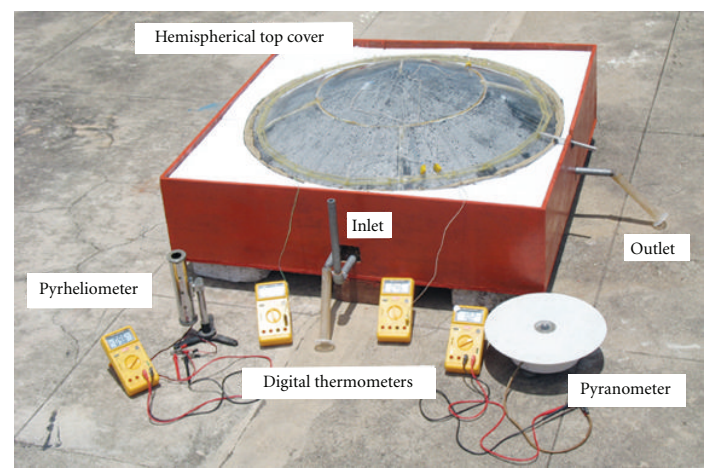

Figure 7: Pictorial view of hemispherical solar still.

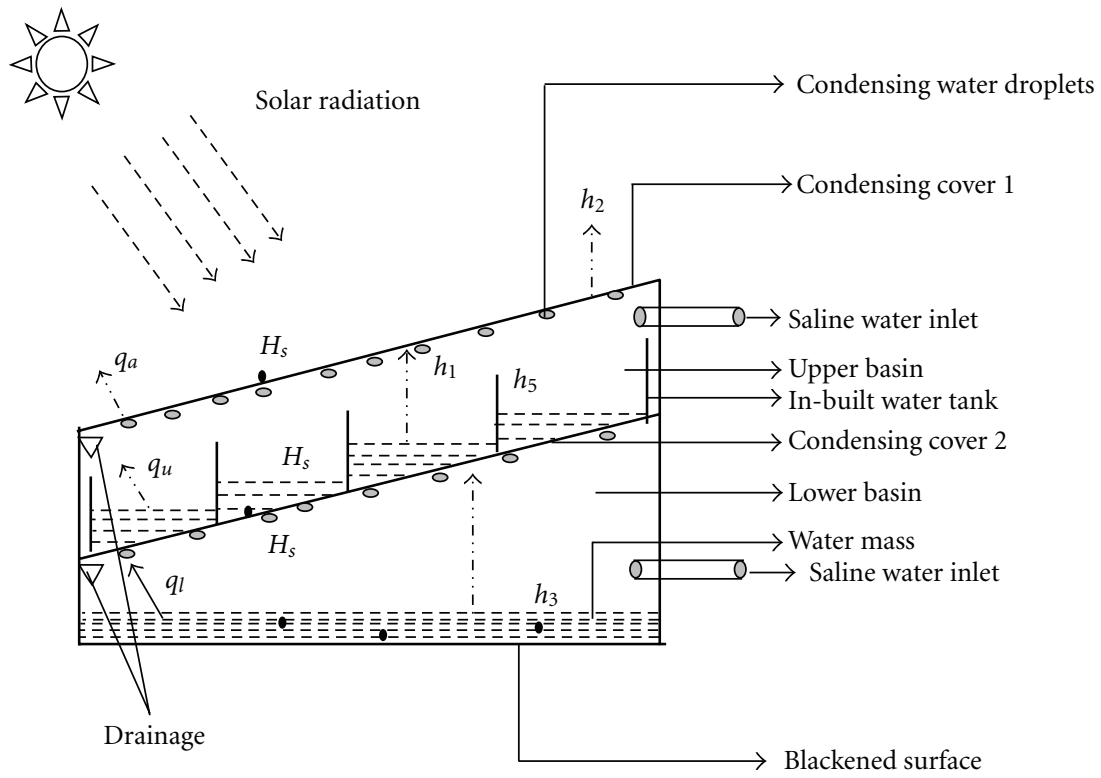

FIgURE 8: The cross-sectional view of double-basin glass solar still.

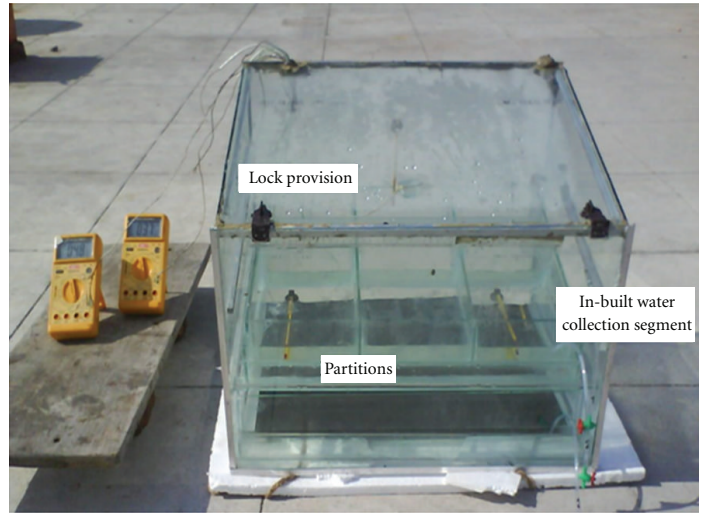

Figure 9: Photographic view of the double-basin glass solar still (front view).

3.6. CPC-TSS-Pyramid Solar Still. The inner and outer tubes are positioned with a $5 \mathrm{~mm}$ gap for flowing cold water to cool the outer surface of the inner glass tube. A circular basin of

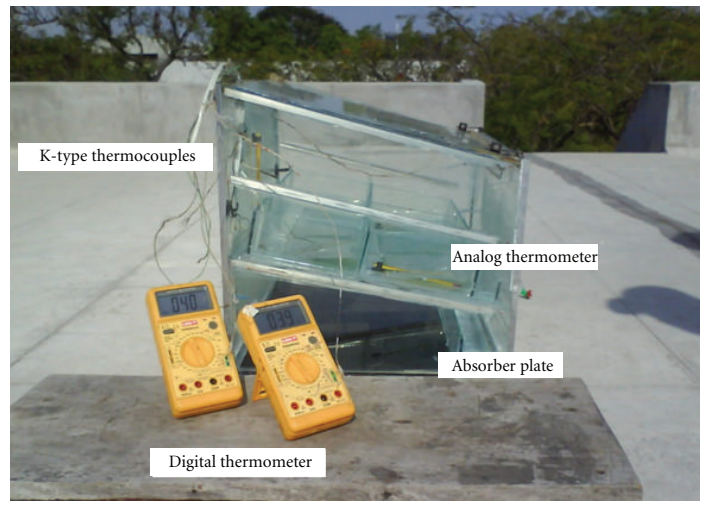

FIGURE 10: Photographic view of the double-basin glass solar still (side view).

dimension $2 \mathrm{~m}$ length and a diameter $0.035 \mathrm{~m}$ was designed and coated with black paint using a spray technique. Pyramid solar still of area $1 \mathrm{~m} \times 1 \mathrm{~m}$ is designed. The bottom of the still 


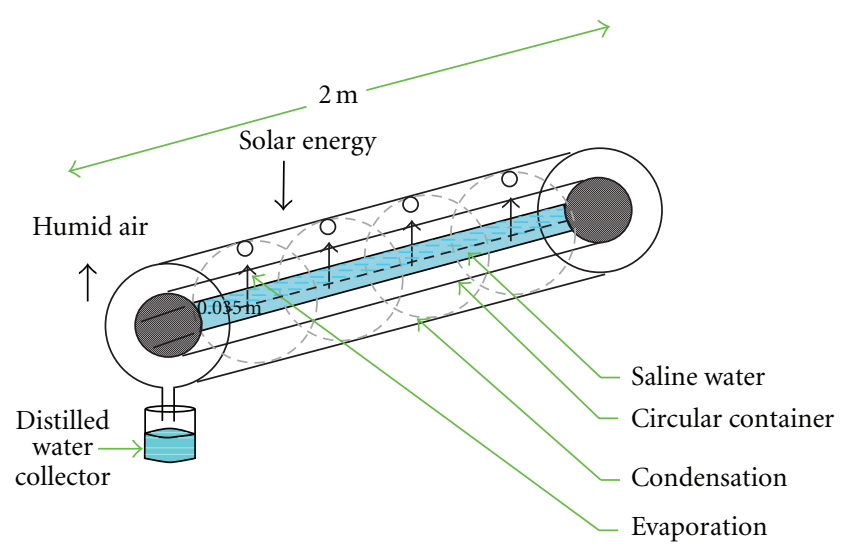

FIGURE 11: Schematic view of tubular solar still.

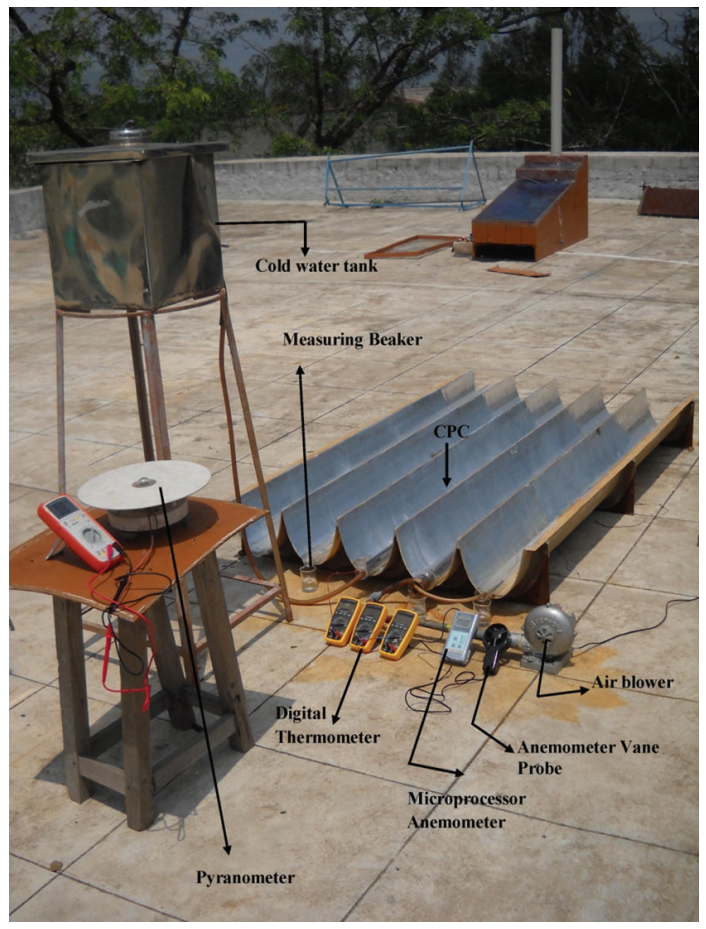

FIGURE 12: Pictorial view of CPC-TSS.

TABLE 1: Design parameters of the tubular solar still.

\begin{tabular}{lc}
\hline Parameters & Values \\
\hline Length of the glass tube & $2 \mathrm{~m}$ \\
Length of the rectangular basin & $1.96 \mathrm{~m}$ \\
Length of the circular basin & $1.96 \mathrm{~m}$ \\
Thickness of the glass tube & $2.5 \mathrm{~mm}$ \\
Weight of glass tube & $2 \mathrm{~kg}$ \\
Weight of the concentric tube & $7 \mathrm{~kg}$ \\
Material-top cover & Borosilicate \\
Absorber & Copper \\
\hline
\end{tabular}

is insulted using saw dust. The solar still insulated with saw dust reduces the cost of fabrication. Consequently, the cost for fresh water production is less. In the view of eco-friendly

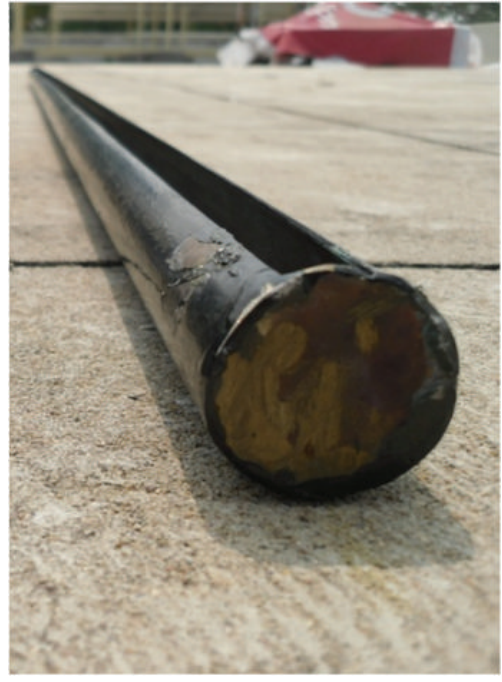

Figure 13: Pictorial view of absorber design in CPC-TSS.

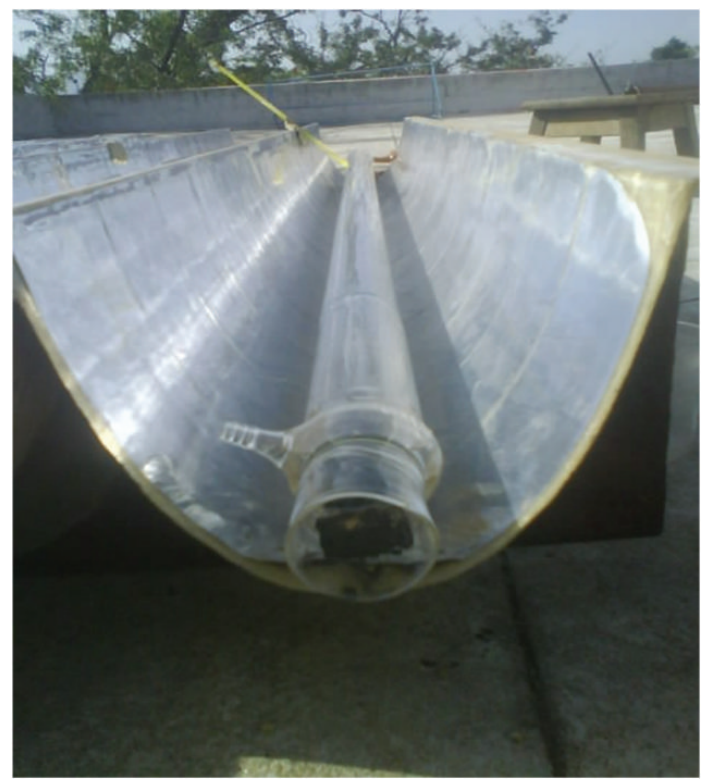

Figure 14: Closeup view of CPC-TSS.

material, saw dust would be a good alternative for glass wool. The pyramid solar still is coupled with a nontracking CPC with help of insulated pipes. The top cover is cooled by flowing cold water at a constant flow rate of $10 \mathrm{~mL} / \mathrm{min}$. It is adjusted by using a pressure head. It is adjusted for maintaining constant water level in the water storage tank initially during the experiment. A graduated measuring jar is used to measure the flow rate. The process is repeated many times until steady cold-water flow in between the tubular cover (See Figures 15 and 16).

3.7. Hemispherical Concentrator Solar Still. A single-slope solar still design with hemispherical concentrator and hemispherical basin absorber are presented as shown in Figures 17 and 18 . The basin of a typical single-slope solar still 


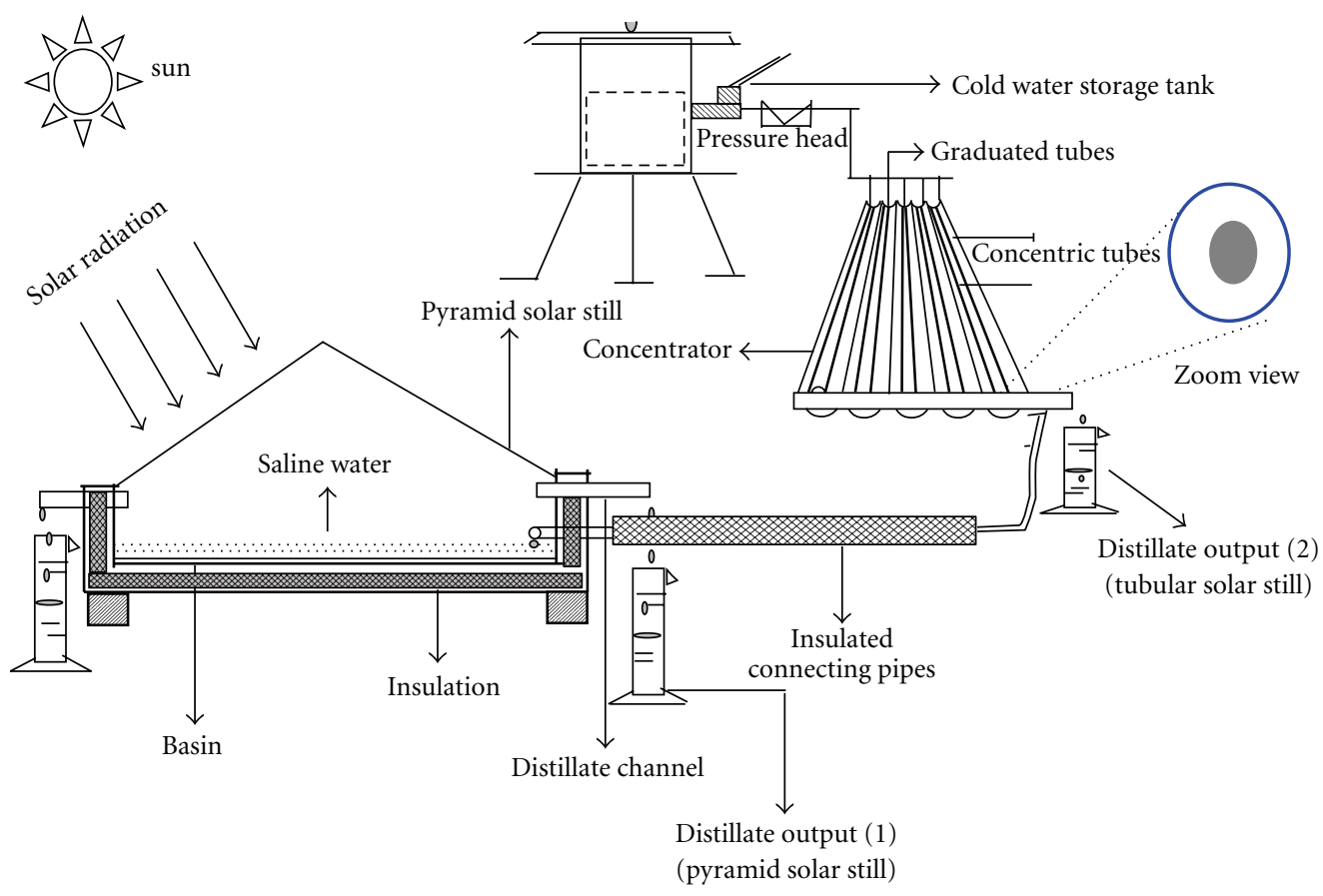

FIGURE 15: Cross sectional view of tubular solar still coupled with pyramid solar still.

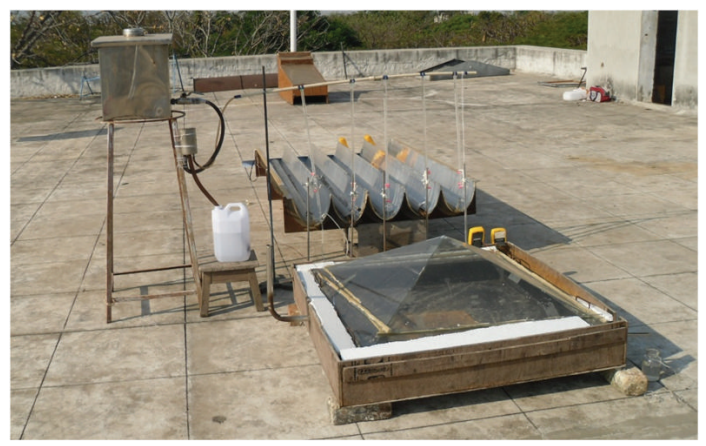

Figure 16: Pictorial view of CPC-pyramid solar still design.

is transformed to a hemispherical shape. It is made up of copper $4 \mathrm{~mm}$ thick. The diameter of the absorber is $0.22 \mathrm{~m}$, and it is welded to the bottom of the still without any water leakage. The bottom and sides of the inner surface of the basins and outer surface are painted black for good solar absorption. $6 \mathrm{~mm}$ inside diameter inlet pipe is provided for pouring water and inserting the thermocouples to measure the temperature inside the still. The top cover is made up of transparent glass sheet of thickness $2 \mathrm{~mm}$ of solar transmittance $90 \%$. The dimension of the glass plate is $0.30 \mathrm{~m} \times 0.30 \mathrm{~m}$. The top cover is tilted at a $16^{\circ}$ slope.

\section{Experimental Techniques and Results}

Experimental setup are performed to evaluate the performance of the six solar still designs under the clear climatic conditions of Coimbatore, India $\left(11^{\circ} \mathrm{N}\right.$ latitude, $77^{\circ} \mathrm{E}$ longitude). The basins are filled with saline water. The experiment was performed on January 1, 2011 to May 30, 2011 with the readings recorded at 30 minutes interval. In order to avoid rapid decrease of the water level in the basin, due to evaporation on clear sunny days, a water tank is connected to each solar still and the same water level is maintained for the six designs in this study. The distilled output of spherical solar still is frequently measured by a measuring jar at regular intervals with the measuring jar placed at the outlet of the solar still. Figure 19 shows the variation of the average daily water collection with respect to time.

\section{Results Analysis and Discussion}

The seven different designs and operational parameters studied to investigate their influence on still productivity are shown in Figure 19. The distillates yield around $2300 \mathrm{~mL} / \mathrm{m}^{2} /$ day obtained for spherical solar still. This type of solar still receives radiation that is transmitted from the spherical transparent surface. At the same time, the water vapor is condensed in the larger spherical surface. Hence more water droplets are condensed on the surface. The contact in the spherical surface still with air is more than a single slope solar still. Hence the rate of condensed distillate yield is increased.

The average daily output of the still is $2900 \mathrm{~mL} / \mathrm{m}^{2} /$ day for the double-basin glass solar still. The evaporation of water in the upper basin is caused mainly by condensation that takes place at the glass cover of the lower basin. As a result, the upper basin continues to produce an appreciable amount of distillate during the night. This demonstrates that the performance of the double-basin solar still is much 


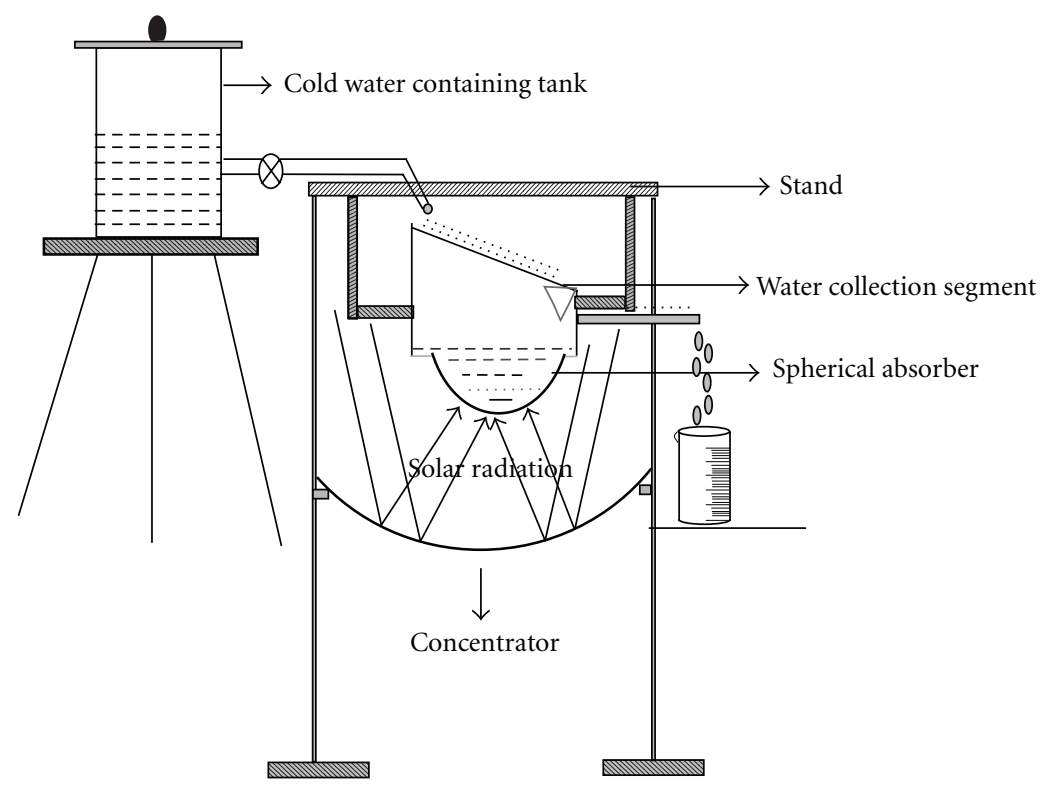

FIgURE 17: Schematic view of spherical basin solar still.
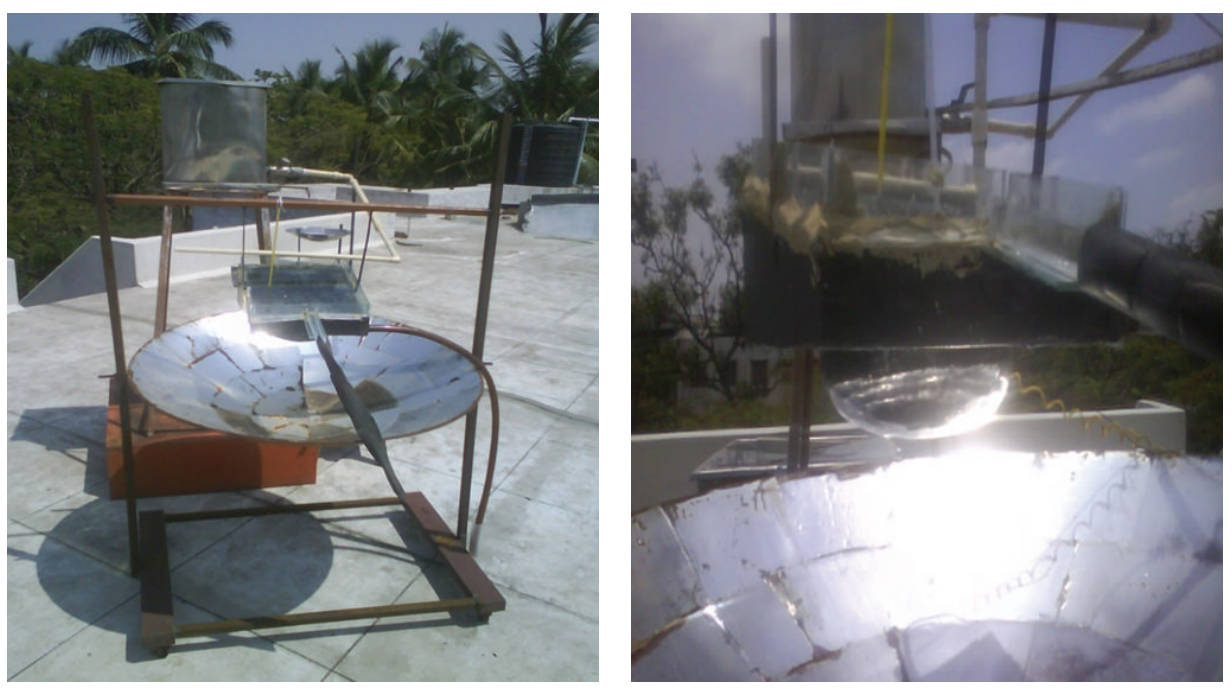

Figure 18: Pictorial view of spherical basin solar still.

better than a single-slope solar still. The basin temperature reached to a maximum within a short intervals of time due to the point focusing of the concentrator. At the same time, corresponding glass temperature is also increased. This increase in cover temperature is due to the minimum separation of distance between top cover and water surface in the basin. So the influence of air temperature due to convection increased the top cover temperature. The rate of evaporation increases due to increase water temperature in the basin. The temperature difference between water and cover temperature increased the distillation yield rate.

The distillate output of the pyramid solar still is $3300 \mathrm{~mL} / \mathrm{m}^{2} /$ day and that from the top cover cooling effect of hemispherical solar still is $3659 \mathrm{~mL} / \mathrm{m}^{2} /$ day. This is because the surface area of the hemispherical solar still is greater than the pyramid solar still. Hence, the hemispherical top cover is contacted with air in high rate. This increases the condensate of more droplets in the top cover. The yield rate is much improved for this type of still when compared to singleslope conventional solar still. A shadow effect creates a small amount of shadow to fall over the water surface during in the morning time as well as in the evening time. This drawback is diminished by reducing the height of the basin as well as hemispherical shape top cover.

The distillate output of the concentrator-coupled singleslope solar still is $2600 \mathrm{~mL} / \mathrm{m}^{2} /$ day while that from the tubular solar still is $4500 \mathrm{~mL} / \mathrm{m}^{2} /$ day. The rapid rate of water productivity is achieved in the concentrator-coupled single slope solar still is 11.00 am to $2.00 \mathrm{pm}$. The total yield of $6928 \mathrm{~mL} / \mathrm{m}^{2}$ is collected for tubular solar still coupled with 


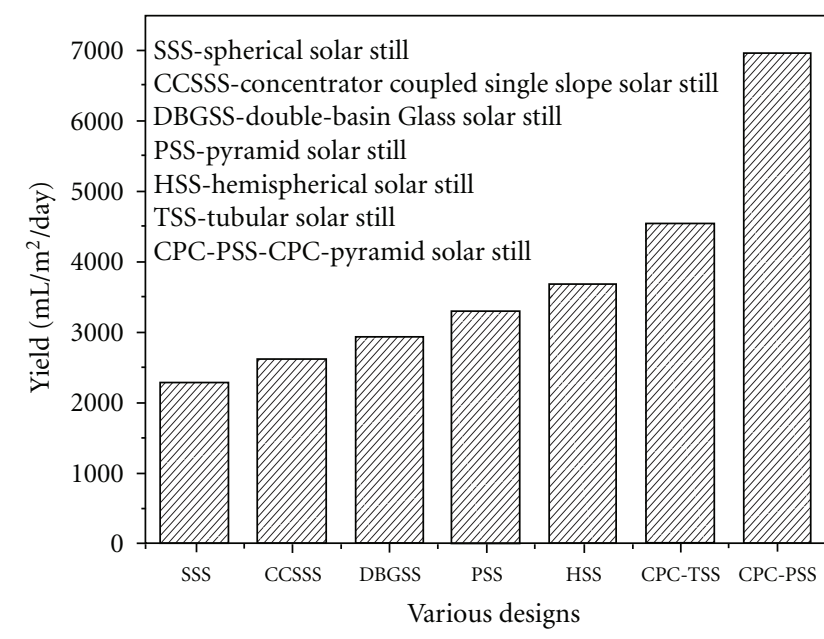

FIGURE 19: Variation of productivity with respect to total productivity.

pyramid solar still. Additionally, the heat extraction of water in the pyramid solar still temperature is further increased by the incoming solar radiation. So the water temperature is increased within a short interval of time. The sudden rise in water temperature induced the evaporative heat transfer in the still. Therefore, the distilled yield increases more than conventional solar still. A further increase in yield rate is also observed for the cooling over the pyramid solar still under same mode of operation. Thus, this result conformed that the assistance of concentrator certainly increased the yield rate of distilled water. The temperature difference $\left(T_{w}-T_{c}\right)$ is one of the key parameter that affects the productivity of a solar still.

This fruitful attempt has been made to analyze different types of stills with different modes of operations. These results reveal that the tubular solar still coupled with pyramid solar still produces higher yield rate. These analyses suggest that the method is consistent to produce a low cost distillation unit for acquiring high pure distilled water. At a time when attention is firmly focused worldwide on control and prevention of pollution, efficient use of energy, and more reliance on renewable energy source, these different types of desalination systems are warmly welcome to fight against environmental pollution, and they are packed with energy saving and environmental friendly features.

\section{Conclusion}

In this paper, the fabrication of seven solar still designs (spherical, pyramidal, hemispherical, double basin, concentrator-coupled CPC tubular, CPC coupled with pyramid solar still) and their performance evaluation in converting brackish water into fresh water for drinking are presented. From the experimental results, tubular solar still coupled pyramid solar still shows the maximum amount of productivity due to the concentrator effect. The productivity of the solar still entirely depends on the climatic parameters as well as increasing the water temperature. This leads to raise the evaporative and convective heat transfer coefficients in the solar still. The concentrator effect plays a vital role to increase the water temperature up to $95^{\circ} \mathrm{C}$ compared to the other types of designs. So evaporative heat transfer is more for tubular solar still, and it is showing the maximum amount of yield.

\section{References}

[1] S. Kalogirou, "Use of parabolic trough solar energy collectors for sea-water desalination," Applied Energy, vol. 60, no. 2, pp. 65-88, 1998.

[2] I. Al-Hayeka and O. O. Badran, "The effect of using different designs of solar stills on water distillation," Desalination, vol. 169, no. 2, pp. 121-127, 2004.

[3] H. E. S. Fath, "High performance of a simple design, two effects, solar distillation unit," Energy Conversion and Management, vol. 38, no. 18, pp. 1895-1905, 1997.

[4] A. M. Tayeb, "Performance study of some designs of solar stills," Energy Conversion and Management, vol. 33, no. 9, pp. 889-898, 1992.

[5] A. J. N. Khalifa, A. S. Al-Jubouri, and M. K. Abed, "Experimental study on modified simple solar stills," Energy Conversion and Management, vol. 40, no. 17, pp. 1835-1847, 1999.

[6] M. Abu-Arabi and Y. Zurigat, "Year-round comparative study of three types of solar desalination units," Desalination, vol. 172, no. 2, pp. 137-143, 2005.

[7] B. I. Ismail, "Design and performance of a transportable hemispherical solar still," Renewable Energy, vol. 34, no. 1, pp. 145-150, 2009.

[8] T. Arunkumar, R. Jayaprakash, D. Denkenberger et al., "An experimental study on a hemispherical solar still," Desalination, vol. 286, pp. 342-348, 2012.

[9] H. E. S. Fath, M. El-Samanoudy, K. Fahmy, and A. Hassabou, "Thermal-economic analysis and comparison between pyramid-shaped and single-slope solar still configurations," Desalination, vol. 159, no. 1, pp. 69-79, 2003.

[10] M. A. Hamdan, A. M. Musa, and B. A. Jubran, "Performance of solar still under Jordanian climate," Energy Conversion and Management, vol. 40, no. 5, pp. 495-503, 1999.

[11] A. A. El-Sebaii, "Effect of wind speed on some designs of solar stills," Energy Conversion and Management, vol. 41, no. 6, pp. 523-538, 2000.

[12] A. A. Al-Karaghouli and W. E. Alnaser, "Experimental comparative study of the performances of single and double basin solar-stills," Applied Energy, vol. 77, no. 3, pp. 317-325, 2004.

[13] Y. P. Yadav, "Transient analysis of double-basin solar still integrated with collector," Desalination, vol. 71, no. 2, pp. 151164, 1989.

[14] G. N. Tiwari, "Enhancement of daily yield in a double basin solar still," Energy Conversion and Management, vol. 25, no. 1, pp. 49-50, 1985.

[15] M. S. Sodha, J. K. Nayak, G. N. Tiwari, and A. Kumar, "Double basin solar still," Energy Conversion and Management, vol. 20, no. 1, pp. 23-32, 1980.

[16] K. K. Murugavel and K. Srithar, "Performance study on basin type double slope solar still with different wick materials and minimum mass of water," Renewable Energy, vol. 36, no. 2, pp. 612-620, 2011.

[17] A. A. El-Sebaii, "Thermal performance of a triple-basin solar still," Desalination, vol. 174, no. 1, pp. 23-37, 2005. 
[18] G. N. Tiwari, S. K. Singh, and V. P. Bhatnagar, "Analytical thermal modelling of multi-basin solar still," Energy Conversion and Management, vol. 34, no. 12, pp. 1261-1266, 1993.

[19] Y. Yamaguchi and H. Sato, "Development of small-scale multieffect solar still," in Proceedings of the ASME International Solar Energy Conference (ISEC'03), pp. 167-173, Kohala Coast, Hawaii, USA, March 2003.

[20] S. Suneja and G. N. Tiwari, "Effect of water flow on internal heat transfer solar distillation," Energy Conversion and Management, vol. 40, no. 5, pp. 509-518, 1999.

[21] S. Suneja and G. N. Tiwari, "Effect of water depth on the performance of an inverted absorber double basin solar still," Energy Conversion and Management, vol. 40, no. 17, pp. 18851897, 1999.

[22] S. Suneja and G. N. Tiwari, "Parametric study of an inverted absorber triple effect solar still," Energy Conversion and Management, vol. 40, no. 17, pp. 1871-1884, 1999.

[23] S. Suneja and G. N. Tiwari, "Optimization of number of effects for higher yield from an inverted absorber solar still using the Runge-Kutta method," Desalination, vol. 120, no. 3, pp. 197 209, 1998.

[24] A. Ahsan and T. Fukuhara, "Mass and heat transfer model of tubular solar still," Solar Energy, vol. 84, no. 7, pp. 1147-1156, 2010.

[25] A. Ahsan, K. M. S. Islam, T. Fukuhara, and A. H. Ghazali, "Experimental study on evaporation, condensation and production of a new tubular solar still," Desalination, vol. 260, no. 1-3, pp. 172-179, 2010.

[26] A. Ahsan and T. Fukuhara, "Condensation mass transfer in unsaturated humid air inside tubular solar still," Annual Journal of Hydraulic Engineering, Japan Society of Civil Engineers, vol. 53, pp. 97-102, 2009.

[27] A. Ahsan and T. Fukuhara, "Evaporative mass transfer in tubular solar still," Journal of Hydroscience and Hydraulic Engineering, Japan Society of Civil Engineers, vol. 26, no. 2, pp. 15-25, 2008.

[28] G. M. Cappelletti, "An experiment with a plastic solar still," Desalination, vol. 142, no. 3, pp. 221-227, 2002.

[29] F. F. Tabrizi, M. Dashtban, H. Moghaddam, and K. Razzaghi, "Effect of water flow rate on internal heat and mass transfer and daily productivity of a weir-type cascade solar still," Desalination, vol. 260, no. 1-3, pp. 239-247, 2010.

[30] F. F. Tabrizi, M. Dashtban, and H. Moghaddam, "Experimental investigation of a weir-type cascade solar still with built-in latent heat thermal energy storage system," Desalination, vol. 260, no. 1-3, pp. 248-253, 2010.

[31] J. T. Mahdi, B. E. Smith, and A. O. Sharif, "An experimental wick-type solar still system: design and construction," Desalination, vol. 267, no. 2-3, pp. 233-238, 2011.

[32] R. Dev and G. N. Tiwari, "Characteristic equation of thermoelectric cooling in a portable active solar still-an experimental study on winter days," Desalination, vol. 269, no. 1-3, pp. 6777, 2011.

[33] J. A. Esfahani, N. Rahbar, and M. Lavvaf, "Utilization of thermoelectric cooling in a portable active solar still-an experimental study on winter days," Desalination, vol. 269, no. 1-3, pp. 198-205, 2011.

[34] F. F. Tabrizi and A. Z. Sharak, "Experimental study of an integrated basin solar still with a sandy heat reservoir," Desalination, vol. 253, no. 1-3, pp. 195-199, 2010.

[35] H. Tanaka, "Tilted wick solar still with flat plate bottom reflector," Desalination, vol. 273, no. 2-3, pp. 405-413, 2011.

[36] V. Velmurugan, M. Gopalakrishnan, R. Raghu, and K. Srithar, "Single basin solar still with fin for enhancing productivity,"
Energy Conversion and Management, vol. 49, no. 10, pp. 26022608, 2008.

[37] K. M. S. Eldalil, "Improving the performance of solar still using vibratory harmonic effect," Desalination, vol. 251, no. 1-3, pp. 3-11, 2010.

[38] A. Ahsan, M. Imteaz, A. Rahman, B. Yusuf, and T. Fukuhara, "Design, fabrication and performance of an improved solar still," Desalination, vol. 292, pp. 105-112, 2012. 

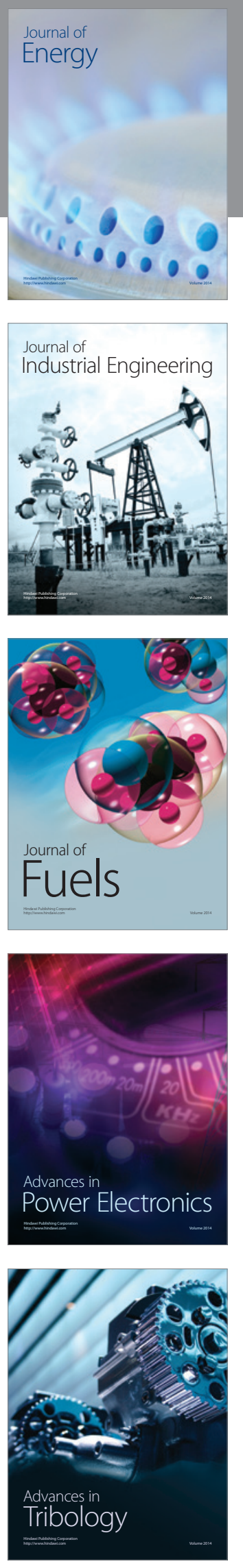
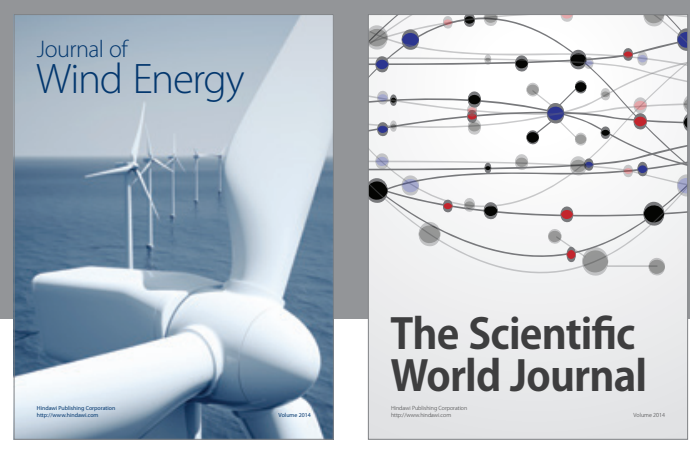

The Scientific World Journal

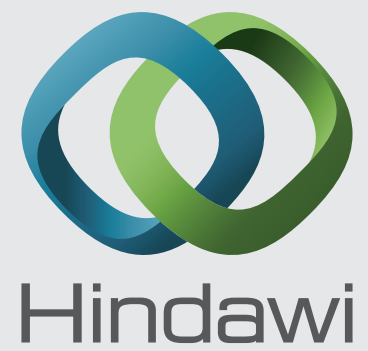

Submit your manuscripts at http://www.hindawi.com
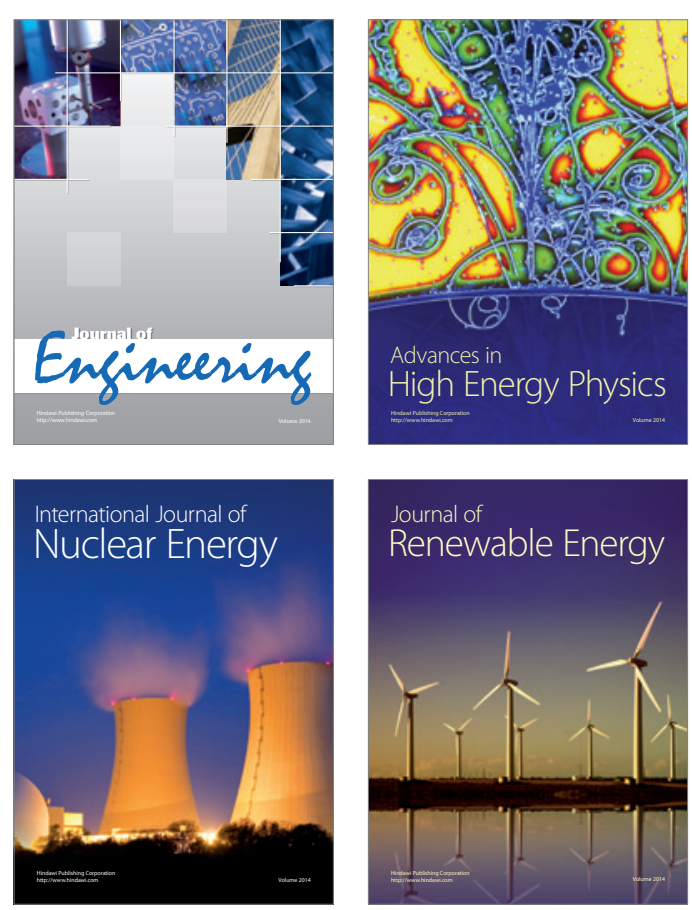

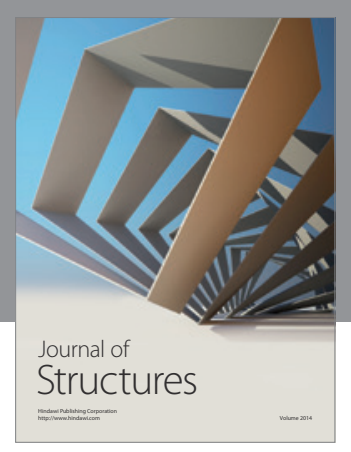

Rotating
Mechinery
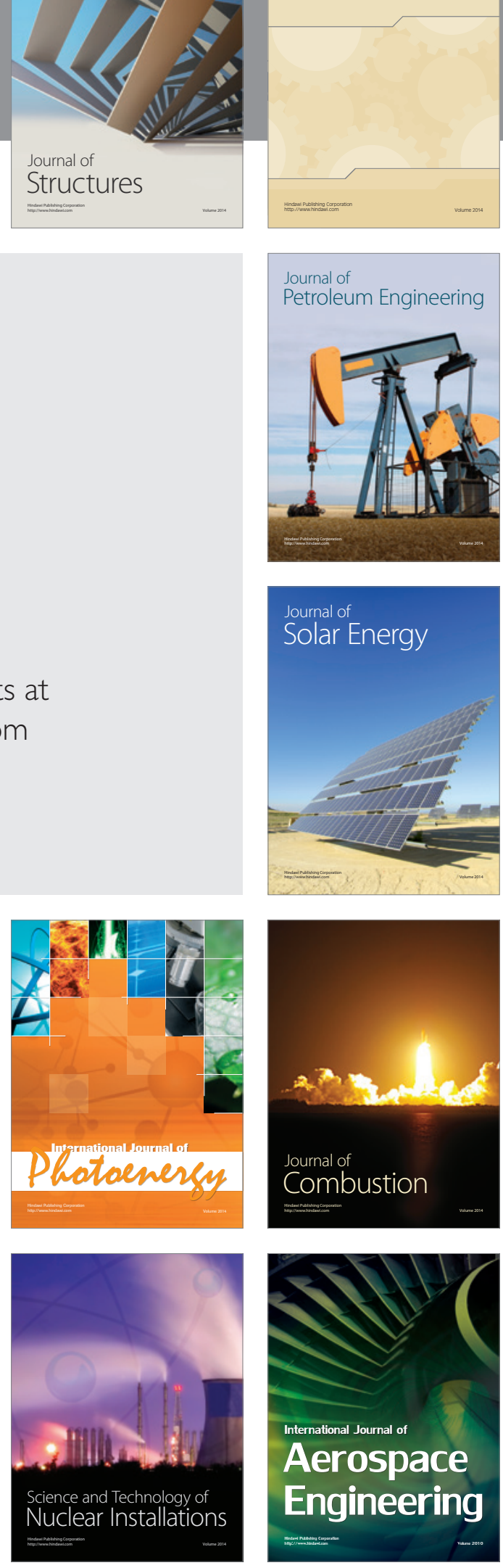